\title{
The role of mindfulness and alexithymia in reducing depression and anxiety in women victims of spouse violence
}

\author{
Sajjad Basharpoor ${ }^{1}$, Setareh Jani ${ }^{2}$ \\ 1- Professor, Department of Psychology, School of Educational Sciences and Psychology, University of Mohaghegh \\ Ardabili, Ardabil, Iran. \\ 2- PhD Student of Psychology, Department of Psychology, School of Educational Sciences and Psychology, \\ University of Mohaghegh Ardabili, Ardabil, Iran (Corresponding Author). $\quad$ E-mail: jani_s11@yahoo.com
}

Received: 07/09/2019 Accepted: 09/12/2019

\begin{abstract}
Introduction: Depression and anxiety of women victims of violence are affected by several personality and cognitive variables such as mindfulness and alexithymia.

Aim: The aim of the present study was to investigate the role of mindfulness and alexithymia in predicting depression and anxiety in women victims of spouse violence.

Method: The research design was descriptive-correlation. The statistical population consisted of 155 women victims of spouse violence who were selected by simple random sampling method and were tested using Toronto Mood Scale (TAS-20), Mindful Attention Awareness Scale (MAAS) and Hospital Anxiety and Depression Scale (HADS). The data were analyzed by SPSS20 software and Pearson correlation coefficient and stepwise regression analyses.

Results: The results showed that mindfulness and alexithymia were able to predict significantly depression and anxiety in women victims of spouse violence.

Conclusion: Mindfulness and alexithymia are influential factors in depression and anxiety in women who are victims of violence. The finding can be considered as preventive programs and provide different treatment strategies for this susceptible group.
\end{abstract}

Keywords: Alexithymia, Anxiety, Depression, Domestic violence, Mindfulness, Women

How to cite this article : Basharpoor S, Jani S. The role of mindfulness and alexithymia in reducing depression and anxiety in women victims of spouse violence. Shenakht Journal of Psychology and Psychiatry. 2020; 6 (6): 55-65 .URL: http://shenakht.muk.ac.ir/article-1-734-fa.pdf

Copyright $\odot 2018$ the Author (s). Published by Kurdistan University of Medical Sciences. This is an open access article distributed under the terms of the Creative Commons Attribution-Non Commercial License 4.0 (CCBY-NC), where it is permissible to download, share, remix, transform, and buildup the work provided it is properly cited. The work cannot be used commercially without permission from the journal. 


\title{
نقش ذهن آكاهى و ناكويى هيجانى در كاهش افسردى و اضطراب زنان قربانى خشونت همسر
}

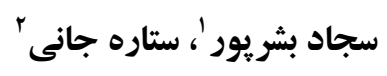 \\ 1.استاد، كروه روانشناسى، دانشكده علوم تريتى و روانشناسى، دانشكاه محقق اردبيلى، اردبيل، ايران.

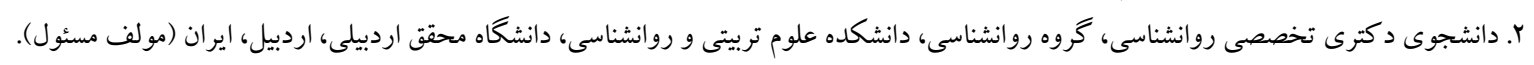 \\ ايميل:yani_s11@yahoo.com
}

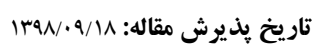

تاريخ دريافت مقاله: 9/19.

جكيده

مقدمه: افسردگى و اضطراب زنان قربانى خشونت از متغيرهاى شخصيتى و شناختى متعددى از جمله ذهن آكاهى و ناكويى هيجانى تأثير مى بذيرد.

هدف: هدف كلى يزٔوهش، بررسى نقش ذهن آكاهى و ناكويى هيجانى در ييشبينى افسردگى و اضطراب زنان قربانى خشونت همسر

روش: طرح يزوهش از نوع توصيفى - همبستكى بود. جامعه آمارى شامل هها زن قربانى خشونت همسر بود كه با روش نمونه گيرى

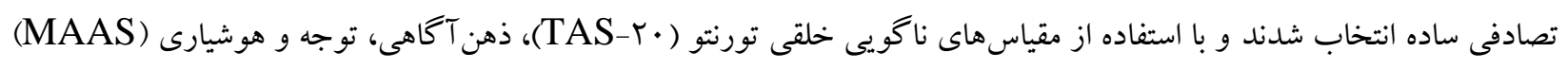

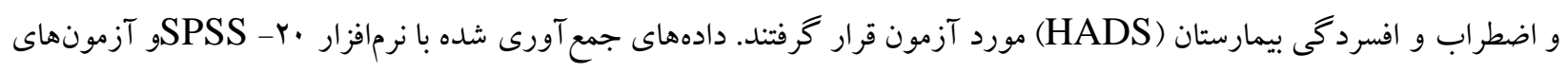
ضريب همبستخى بيرسون و رگرسيون گامبه گام تحليل شد.

يافتها: نتايج نشان داد كه ذهن آكاهى و ناكويى هيجانى قادر هستند، افسردگى و اضطراب زنان قربانى خشونت همسر را به طور معنى دار بيشبينى كنند. نتيجه كيرى: ذهن آكاهى و ناگويى هيجانى از عوامل تأثير گذار در افسردى و اضطراب زنان قربانى خشونت مىباشند كه اين يافته

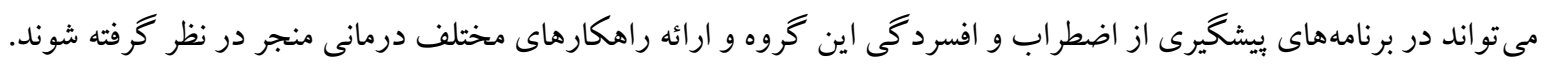
كليدوازهها: اضطر اب، افسردگى، خشونت، زنان، ذهن آكاهى، ناكويى هيجانى 
نشان مىدهند. ذهن آگاهى و ناگويى هيجانى از جمله

مقدمه

متغيرهايى هستند كه بر ميزان افسردگى و اضطراب افراد

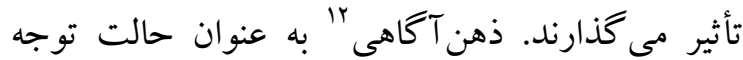
برانگيخته و آكاهى از آنجه كه در لحظه كنونى اتفاق مى افتد، تعريف شده است كه به فرد امكان مىدهد تا به جاى آنكه به رويدادها به طور غيرارادى و بىتأمل باسخ

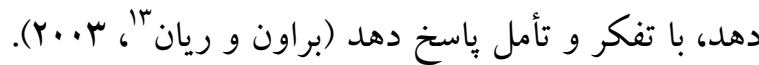
يزوهشهاى متعدد حاكى از ارتباط منفى مهارتهاى

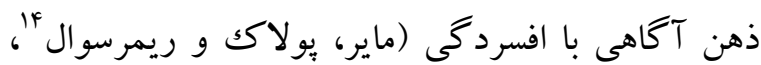

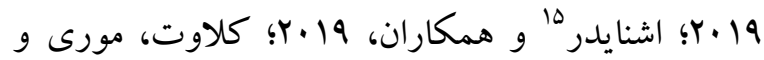

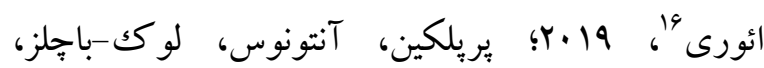

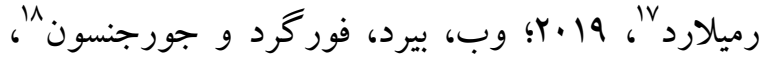
19 ·r، قهارى و همكاران، IV) همكاران، 19 +r؛ اشنايدر و همكاران، 19 +r؟؛ بريلكين و و

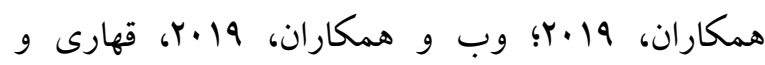

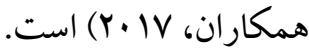
عقيده بر اين است كه ناكويى هيجانى 19 نيز عاملى خطرساز براى بسيارى از اختلالهاى روانيزشكى است. ناگويى هيجانى، سازهاى است متشكل از دشوارى در شناسايى احساسها، توصيف آنها و جهت گيرى فكرى بيرونى. اين نارسايى مانع تنظيم هيجانها مىشود و ساز گارى موفقيت آميز را مشكل مى سازد (فيتز، والنسيا و

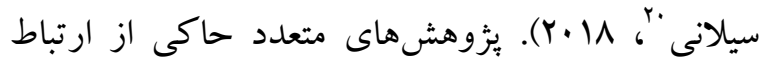

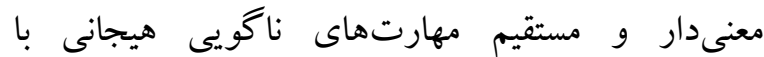

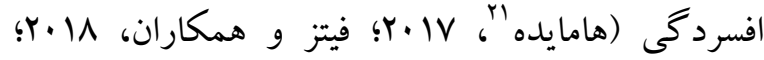

12 - Mindfulness

13 - Brown \& Ryan

14 - Mayer,Polak, Remmerswaal

15 - Schneider

16 - Calvete, Morea, Orue

17 - Perepelkin, Antunes, Luke Boechler, Remillard

18 - Webb, Beard, Forgeard, Björgvinsson

19 - Alexithymia

20 - Fietz, Valencia, Silani

${ }^{21}$ - Hamaideh
خشونت خانكى ' عليه زنان داراى ابعاد متعدد فيزيكى، روانى (مانند تهلديد، تحقير)، اجتماعى (مانند در انزواى اجتماعى قرار دادن)، اقتصادى و جنسى است (آقاخانى، افتخارى، زارعى خير آباد، موسوى، Y (Y). خشونت عليه زنان يكى از مسائل مهم و متداول در مناطق شهرى و روستايى اكثر جوامع بشرى است (آيتون، بريجارد و

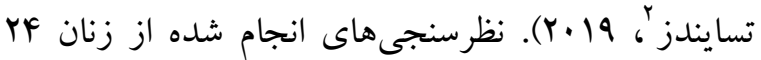

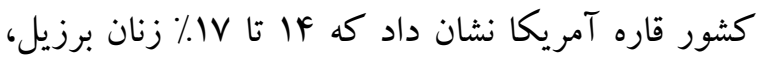

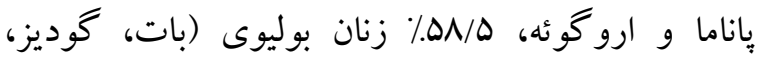

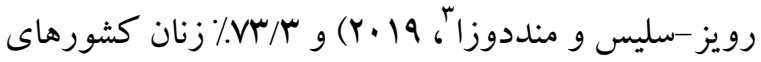
عربى دجار خشونت مىباشند (هاوكرافت مُ و همكاران،

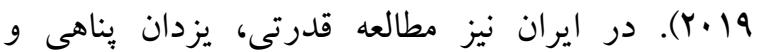

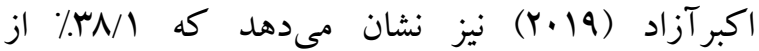
آزمودنىها يكى از انواع خشونت خانكى را تجربه مى كنند. خشونت خانگیى براى زنان آثار روانشناختى جدى

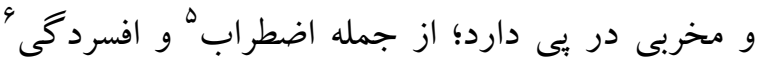

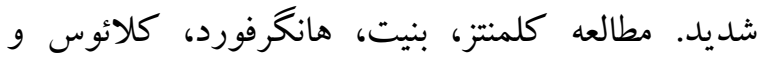

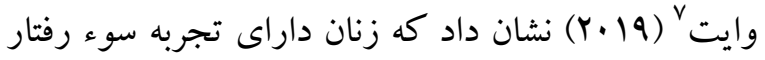
فيزيكى و انواع خشونتها، ميزان بالاترى از افسردگى (هاوكرافت و همكاران، 19 +r؛؛ دوال، بيترى و بائوتير،

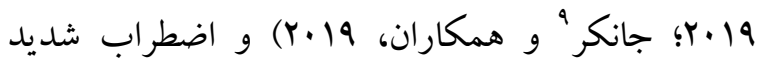

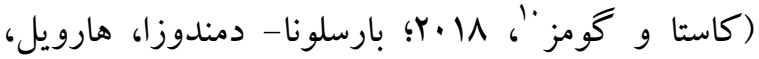

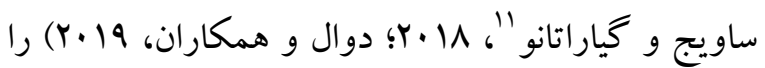

\footnotetext{
1 - Domestic violence

2 - Ayton, Pritchard, Tsindos

3 - Bott, Guedes, Ruiz-Celis, Mendoza

4 - Hawcroft

5 - Anxiety

6- Depression

7 - Clements, Bennett, Hungerford, Clauss, Wait

8 - Duval, Pietri, Bouteyre

9 - Jonker

10 - Costa, Gomes

${ }^{11}$ - Barcelona de Mendoza, Harville, Savage, Giarratano
} 
كه شامل rצr نفر بودند. بر اساس جدول كرجسى و

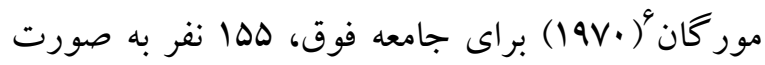

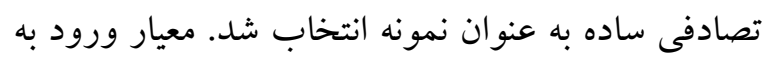
يثزوهش شامل: داشتن بيرونده فعال همسر آزارى در حوزه سلامت اجتماعى مراكز خدمات جامع سلامت

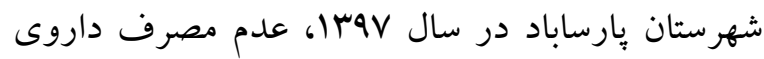
روانيزشكى، عدم ابتلاى همزمان به بيمارى مزمن بهن جسمى، كمتوانى ذهنى و عدم سوءمصرف مواد و عدم فوت يكى از عزيزان در سه ماه كذشته بود كه از طريق برونده شخص و خودگزارشى آنها مورد بررسى قرار

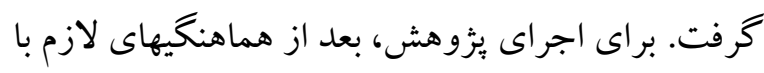
شبكه بهداشت و درمان و مسول حوزه سلامت اجتماعى آن شبكه در شهرستان پارساباد از بين بوץ برونده فعال همسر آزارى (داراى حداقل يكى از انواع خشونت جسمى، روانى، اقتصادى و يا جنسى) در f مركز خدمات جامع سلامت شهرستان، لها نفر بصورت تصادفى ساده انتخاب شد. بعد از توضيح اهداف يزوهشى و كسب رضايت براى همكارى برسشنامه ها بر روى افراد نمونه اجرا شد. بعد از حذف يرسشنامههاى ناقص داده هاى \&q إبرسشنامه تحليل شد.

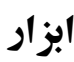
مقياس ناكويى خلقى توزنتو: اين آزمون ·r سؤ الى است كه سه زير مقياس دشوارى در تشخيص احساسها، دشوارى در توصيف احساسها و تفكر عينى را در اندازه ينج درجهاى ليكرت از نمره ا تا نمره ه مىسنجد. در نسخه فارسى اين مقياس، ضرايب آلفاى كرونباخ براى ناكويى هيجانى كل و سه زير مقياس دشوارى در تشخيص احساسها، دشوارى در توصيف احساسها و

${ }^{6}$ - Krejcie, Morgan
همينگك، هادوك، شاو و برات'، 19.19) و اضطراب

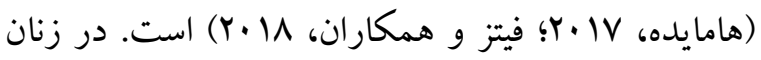
قربانى خشونت نيز، ناگويى هيجانى با افسردگى همبسته

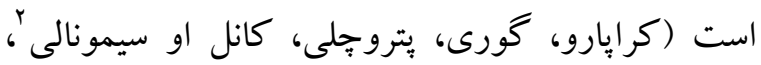

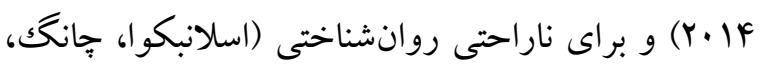

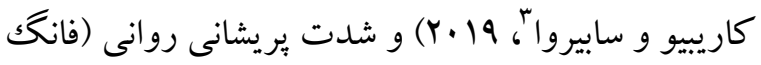

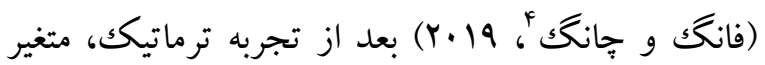
ييشبين مهمى محسوب مىشود. اكثر مطالعاتى كه تأثيرات منفى خشونت همسر بر سلامت روان زنان را بررسى كرده است، از كشورهاى داراى در آمد بالا بوده

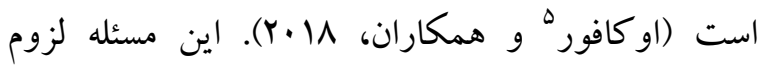
بررسى موضوع خشونت در كشورها و فرهنگكاى مختلف را برجسته مى كند. هم جنين با توجه به اينكه خشونت عليه زنان مانعى براى توسعه و خطرى جدى براى سلامت عمومى است، شناخت متغيرهاى تأثير گذار بر افسردگى و اضطراب اين قشر جهت فراهم كردن درك بيشتر از خشونت خانكى به منظور تدوين برنامهريزىهاى بيشخيرانه و درمانى و رسيدگى به اين

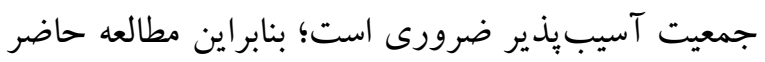
با هدف بررسى نقش ذهن آكاهى و ناكويى هيجانى در بيش بينى افسردگى و اضطراب زنان قربانى خشونت خانكى اجرا شد.

روش طرح بزوهش حاضر، توصيفى - همبستخى است. جامعه آمارى بزّوهش شامل كليه زنان متأهل قربانى خشونت

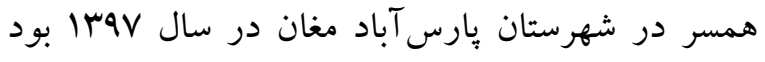

\footnotetext{
1- Hemming, Haddock, Shaw, Pratt

2 - Craparo, Gori, Petruccelli, Cannella, Simonelli

3. Slanbekova, Chung, Karipbaev, Sabirova

4- Fang, Chung

5 - Okafor
} 


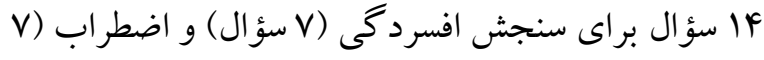
سؤال) در بيماران جسمى، روانى و حتى افراد سالم است. هر سؤال به وسيله يكك مقياس جهار نمرهاى امتيازدهى مىشود. حداكثر امتياز براى هر يكك از زير مقياسهاى افسردگى و اضطراب 21 است. امتياز بالاى لا در هر هر دو زمينه نشانه وجود يكك اختلال روانيزشكى جدى، اصنى •1-1 بينابينى و V-1 - طبيعى محسوب مىشود. يايايى يرسشنامه بر حسب آلفاى كرونباخ براى هر يك از زير

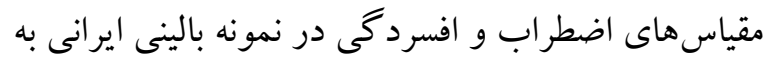

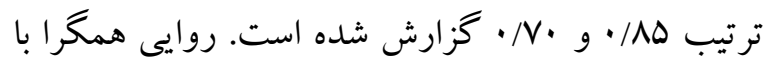
دو يرسشنامه اضطراب و افسردگى بك براى زير مقياس

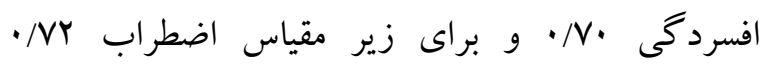
كزارش شده است (كاويانى، صيفوريان، شريفى،

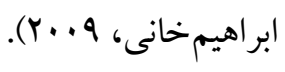

\section{يافتهها}

به منظور بررسى رابطهى ناگويى هيجان و ذهن آكاهى با

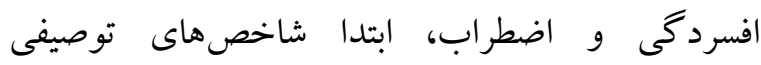
متغيرهاى ئزوهش ارائه مى گردد. جدول شماره 1 ميانگين، انحراف معيار و فراوانى متغيرهاى مورد مطالعه يُزوهش را نشان مى دهد.

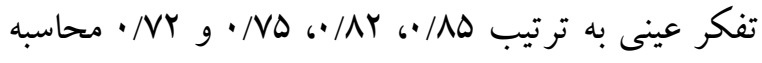
شد كه نشانه همسانى درونى خوب مقياس است. يايايى 9V باز آزمايى مقياس ناكويى خلقى-ب.r در يك نمونه

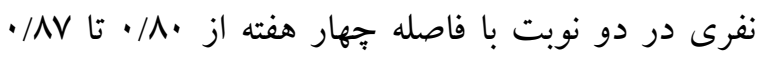
براى ناكويى هيجانى كل و زير مقياسها تأييد شد. روايى همزمان اين مقياس نيز برحسب همبستخى بين زير مقياسهاى آزمون و مقياسهاى هوش هيجانى، بهزيستى روانشناختى و درماندگى روانشناختى بررسى و تأييد

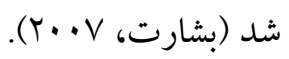

\section{يرسشنامه ذهن آعاهى، توجه و هوشيارى (MAAS): اين} آزمون توسط براون و ريان (r....Y) طراحى شده است. اين يرسشنامه ها سؤالى بهصورت ليكرت نمره گذارى 9. است. روايى اين مقياس مطلوب است (براون و ريان،

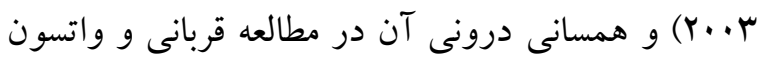
(Y.D)

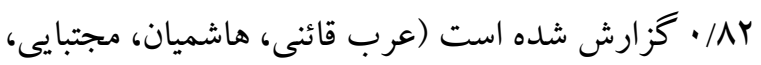

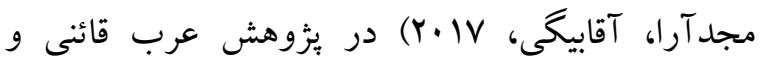

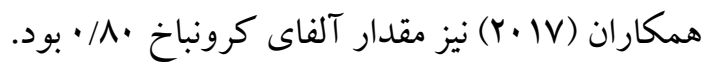
مقياس اضطراب و افسردكى بيمارستان (HADS): اين آزمون توسط اسنايت (س人19) ساخته شده است و شامل

\begin{tabular}{|c|c|c|c|}
\hline انحراف استاندارد & ميانغين & تعداد & متغير ها \\
\hline $\mid r / 49$ & $<q / 91$ & $1 F q$ & ناكويى هيجانى \\
\hline $1 Y / 99$ & $r N / \cdot 1$ & $19 q$ & ذهن آكاهى \\
\hline$F / A I$ & 1.194 & $14 q$ & افسردمى \\
\hline $4 / 90$ & $11 / 91$ & 149 & اضطراب \\
\hline
\end{tabular}

جدول 1 آماره توصيفى متغيرهاى بيشيين و ملاكى

استفاده شد كه نتايج آن در جدول شماره Y درج شده

براى تعيين رابطه ناگويى هيجانى و ذهن آكاهى با افسردگى و اضطراب از ضريب همبستى ييرسون است. 
جدول r ميزان همبستكى ناكويى هيجانى و ذهن آكاهى با افسردكى و اضطراب

(F)

(

( $(r)$

(1)

متغير ها

\begin{tabular}{|c|c|c|c|c|}
\hline & & & 1 & (1)نا كويى هيجانى \\
\hline & & 1 & $-\cdot / T V_{\text {米米 }}$ & هن آكاهى \\
\hline & 1 & $-\cdot / \Gamma 4$ 米米 & $\cdot / \Gamma Y$ 米米 & (ז) افسردىى \\
\hline 1 & $\cdot / \Upsilon 99_{*}$ & $-\cdot /$ 个米米 & $\cdot / \Gamma \Delta$ 光米 & (†) اضطر اب \\
\hline
\end{tabular}

$\mathrm{P}<. / .1 * *$

براى تحليل بيشتر دادهها و جهت تعيين سهم ناگويى از تحليل رگرسيون جند گانه گام به گام استفاده شد كه هيجانى و ذهن آكاهى در بيشبينى افسردگى و اضطراب

\begin{tabular}{|c|c|c|c|c|c|c|c|c|c|c|c|}
\hline دارى معى & $\overline{\mathbf{t}}$ & Beta & خطاى & B & مارى & $\mathbf{F}$ & خغطاى & $\begin{array}{c}\text { R } \\
\text { شده } \\
\text { اصلاه }\end{array}$ & $\mathbf{R}^{2}$ & $\mathbf{R}$ & ميشير بين \\
\hline$\cdot / \ldots$ & $-F / V F$ & $-\cdot$ - TaY &.$/ . Y q$ & $-/ I T V$ & $\cdot / \ldots$ & YY/MA & $F / \Delta$. &.$/ 1 T \Delta$ & . & . Mar & كام 1 \\
\hline$\cdot / \cdot r$ & $r / 19$ & $\cdot / T F A$ & $\cdot / \cdot r$. &.$/ .99$ & $\cdot / \ldots$ & $9 \cdot 19$. & $F / T V$ & $\cdot / I V V$ & $\cdot / M M$ & - / FMF & كام r \\
\hline
\end{tabular}

جدول شماره r نشان مىدهد كه ذهن آكاهى و ناگويى افسردگى سا درصد و سهم ذهن آكاهى و ناكويى

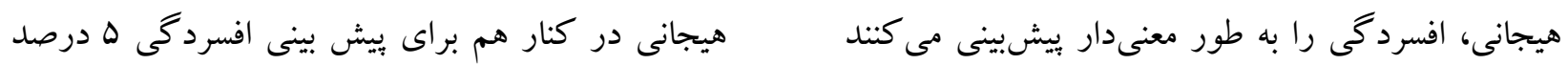

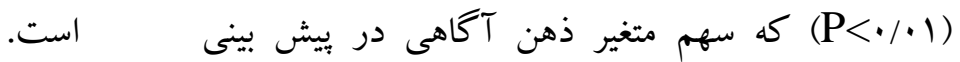

جدول ب نتايج تحليل ركرسيون جند كانه اضطراب بر اساس ناكويى هيجانى و ذهن آكاهى

\begin{tabular}{|c|c|c|c|c|c|c|c|c|c|c|c|}
\hline مارى معنى & $\mathbf{t}$ & Beta & خطاى & B & دارى & $\mathbf{F}$ & تخميار & $\begin{array}{c}\text { R Rلاح } \\
\text { شده }\end{array}$ & $\mathbf{R}^{2}$ & $\mathbf{R}$ & ميشير هاى \\
\hline.$/ \cdots$ & $-F / 9 \Lambda$ & $-\cdot /{ }^{\prime} \wedge$. & $\cdot / \cdot Y \Lambda$ & $-\cdot / 1{ }^{\prime} q$ & $\cdot / \ldots$ & YF/A. & $r / r r$ & ./Ira & ./IFF & $\cdot / \pi \Lambda$. & كام 1 \\
\hline.$/ \ldots$ & $r / q \mu$ & $\cdot / T V V$ & $\cdot / \cdot Y \Lambda$ & $\cdot / / . r$ & $\cdot / \ldots$ & $r \cdot / \cdot r$ & $k / 10$ & $\cdot / r \cdot \Delta$ &.$/ Y 10$ &.$/ 494$ & كام r \\
\hline
\end{tabular}


بذيرى فعاليتهاى شناختى را افزايش مىدهد و نشخوار فكرى، بيش تعميمى در حافظه سر كذشتى و ارزيابى هاى خود انتقاد گرايانه را كاهش و فرايندهاى شناختى مفيد ماند مشاهده گرىى غير قضاوتى محتواهاى ذهنى رال افزايش مىدهد؛ بنابراين براى افت خلق افسرده مفيد واقع مىشود. همجنين ذهن آكاهى نوعى كنترل فرايند توجه است كه منجر به ايجاد آكاهى فراشناختى مىشود. فرايندهاى فراشناختى اجازه توسعه نوعى حالت تمركز زدايى از افكار را فراهم مى كنند. در اين حالت افكار به جاى اينكه ضرور تاً بازنمايىهاى مستقيمى از واقعيت تعبير شود به عنوان رويدادهاى ذهنى كذرا ادراكى مى ئوند. يكى از مزاياى جنين شيوهاى براى توجه كردن، ايجاد مفهومى براى توجه كردن، ايجاد مفهومى انعطاف بذيرانه از خود و برقرارى رابطهاى روان تر و سالم تر با

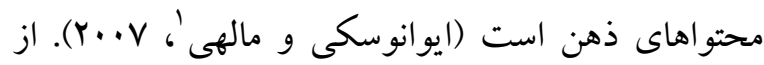
سوى ديخر مطالعه ديون و همكاران (Y) (Y. نشان مى دهد كه ذهن آكًاهى به واسطه افزايش عزت نفس، انعطاف يذيرى و توانمندسازى، همبستكى منفى با نشانهاى

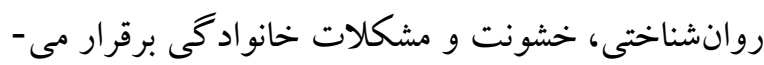

رابطه معكوس ذهن آكاهى با اضطراب را نيز جنين مىتوان تبيين كرد كه ذهن آكاهى از طريق تأثيرات فيزيولوزيكك و نيز كاهش سطح استرس، تأثير بر فرآيند مربوط به آرامسازى، افزايش هشيارى، كاهش قضاوت نسبت به خود، كاهش تفكرات مربوط به كذشته و آينده، كاهش نشخوار ذهنى، تمركز بر رويدادهاى زمان حال و غيره مىتواند موجب كاهش اضطراب شود (مظفرى

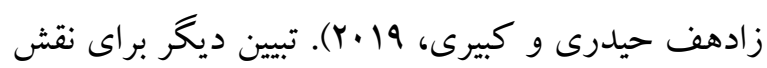

جدول شماره F نشان مىدهد كه ذهن آكاهى و ناكويى هيجانى، اضطراب را به طور معنىدار بيشبينى مى كنند (P<•/ (1) اضطراب ff If درصد و سهم ذهن آكاهى و ناكويى هيجانى در كنار هم براى بيش بينى اضطراب V درصد است.

\section{بحث}

مطالعه حاضر با هدف بررسى نقش ذهن آكاهى و ناگويى هيجانى در بيشينى افسردگى و اضطراب زنان قربانى خشونت همسر انجام شد كه يافتها نشان داد، ذهن آكاهى و ناكويى هيجانى با افسردگى و اضطراب اين زنان رابطه معنىدار دارند و قادر به بيشبينى معنىدار ميزان افسردگى و اضطراب اين افراد هستند. نتيجه مطالعه حاضر در باب ارتباط معكوس و معنىدار ذهن آكاهى و

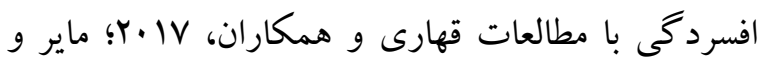

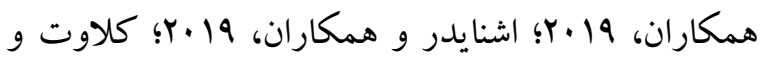

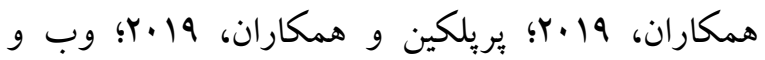

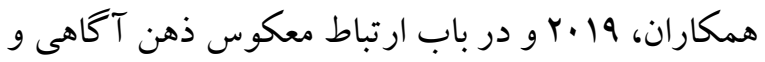
اضطراب با مطالعات قهارى و همكاران، IV. r. ماير و

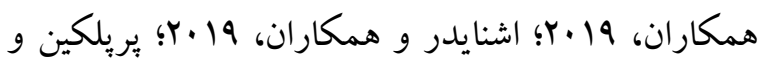

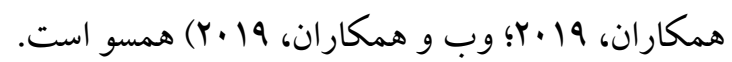
اين يافته را كه هرقدر ذهن آكاهى فرد بالاتر باشد، ميزان

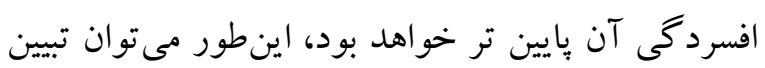

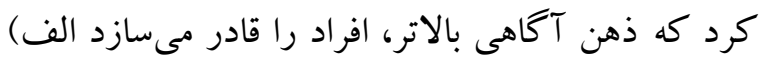
محتواهاى مخرب و الخوهاى عادتى ذهن را شناسايى كنند، ب) اين گونه اطلاعات را به شيوهاى غير قضاوتى مورد بردازش قرار دهند تا توانايى شان براى انتخاب بين كزينه هاى مختلف تسهيل شود. اين رويكرد انعطاف

\footnotetext{
${ }^{1}$ - Ivanoski \& Malhi
} 
اين دو مؤلفه به لحاظ نظرى مىتوان ارتباط برقرار كرد

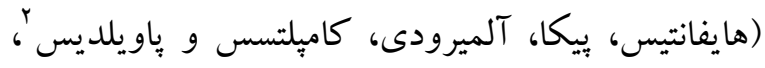
(Y.1) ناكويى هيجانى بالاتر دجار شكست در تنظيم هيجانات منفى مىشوند. افرادى كه قادر به شناسايى هيجانات منفى و تنظيم آن نيستند، مشكلات زيادى رادر زمينه ساز گارى بهتر با شرايط استرسزا تجربه مى كنند. علاوه بر اين، دشوارى در شناسايى و توصيف هيجان با متغيرهايى نظير رفتارهاى غير انطباقى بيمارى و حساسيت بالا و استفاده از راهبردهاى مقابلهاى ناسالم براى مديريت هيجانات منفى

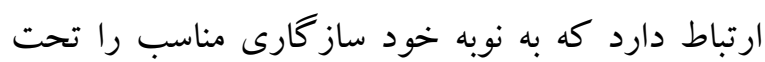

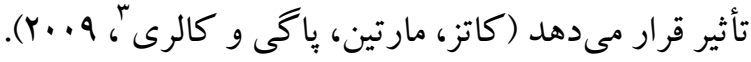
در زمينه ارتباط مستقيم ناگويى هيجانى با اضطراب نيز مىتوان مطرح كرد كه ناكويى هيجانى كه با تفكر عينى، قدرت تجسم محدود، كاهش خياليردازىها و تمركز بر امور ساده، سطحى، عينى و خارجى مشخص مىشود، مىتواند به عنوان جايخزينى مكمل براى مكانيسم جبر ان

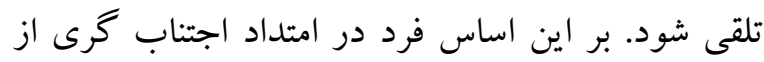
عواطف دردناك مبتنى بر تهييجهاى فيزيولوزيك از طريق تفكر عينى، هرجه بيشتر از دنياى درونى و واقعيتهاى نخران كننده ذهنى فاصله مى گيرد و سدسازى خود در مقابل فشارهاى ناشى از اين عواطف دردناكى را تكميل مى كند. شواهد نشان مىدهد اضطراب مى تواند ناشى از حالتهاى وايسرونده رشد هيجانى باشد و بنابراين به فراخوانى ويز گیىهاى ناخويى هيجانى منجر

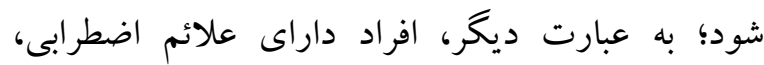
هيجانهاى خود را كمتر مىيذيرند و بيشتر از راهبردهاى
ذهن آكاهى در كاهش اضطراب، اين است كه ذهنآكاهى فرد را از طريق آكاهى لحظه به لحظه و جهت كيرى رفتارى مبتنى بر مسئوليت عاقلانه (جاى واكنش يذيرى خود كار)، به ايجاد رابطهاى متفاوت با احساس هاى درونى و حوادث بيرونى قادر مى سازد. ذهن آكاهى مى تواند با به كار گيرى هدفمند كار كردهاى عالى ذهن از جمله توجه، آكاهى، نخرش مهربانانه، كنجكاوى و و دلسوزى، به طور مؤثر بر واكنشهاى هيجانى (از طريق

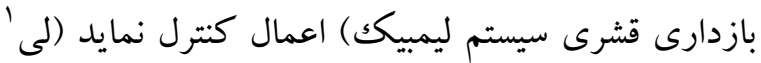

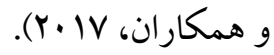
يافته ديخر مطالعه حاضر مبنى بر رابطه مستقيم و معنىدار

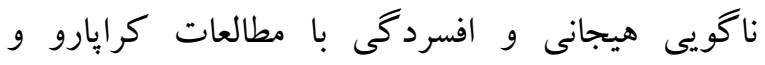

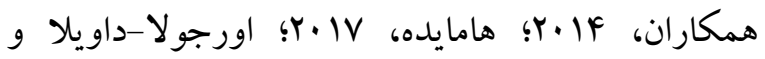

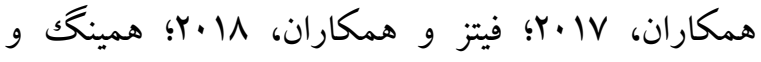

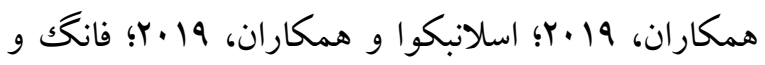
جانگك، 19 19 و در زمينه ارتباط معنىدار اضطراب و و ناكويى هيجانى با مطالعات هامايده، IV همكاران، 11 + ب؛ همينگك و همكاران، 19 • ب؟ اسلانبكوا و

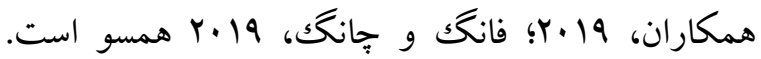
يثزوهشهاى متعدد حاكى از ارتباط معنىدار و مستقيم مهارتهاى ناگويى هيجانى با و اضطراب (هامايده،

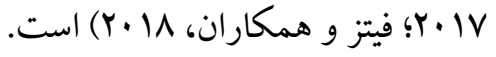
در تبيين اين يافته مىتوان گفت، از آنجا كه توانايى ضعيف در شناسايى و ابراز هيجانها، ظرفيت بايين

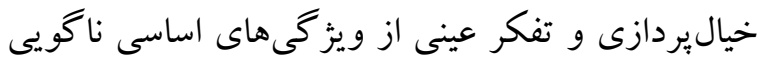
هيجانى است و سركوبى عواطف، توانايى كاهش يافته براى ابراز هيجانى به ديخران و خلق بايين و ناراحت نيز از ويز گیىهاى اساسى در علائم افسردگى است، بِ بـ بين

2 - Hyphantis, Paika, Almyroudi, Kampletsas, Pavlidis

3 - Katz, Martin, Page, Calleri
1 - Lee 
افرادى كه در اين يُووهش ما را يارى كردند تشكر و

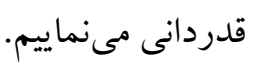

\section{References}

Aghakhani N, Eftekhari A, Zarei Kheirabad A, Mousavi E. (2012). investigation of husbands' violence against women and the impact of various factors on the incidence of them women referred to forensic medicine in the city of Urmia. J Forensic Med, 18 (2-3),69-78. [Persian]

Arab Ghaeni M, Hashemian K, Mojtabai M, Majd Ara E, Aghabeiki A. (2017). The effect of mindfulness training (MBSR) on the increasing assertiveness among anxious students. J Urmia Univ Med Sci, 28(2),119129.

Ayton D, Pritchard E, Tsindos T. (2019). Acquired Brain Injury in the Context of Family Violence: A Systematic Scoping Review of Incidence, Prevalence, and Contributing Factors. Trauma Violence Abuse.

Barcelona de Mendoza V, Harville EW, Savage J, Giarratano G. (2018). Experiences of Intimate Partner and Neighborhood Violence and Their Association With Mental Health in Pregnant Women. J Interpers Violence, 33(6), 938-959.

Besharat MA. (2007). Reliability and factorial validity of Farsi version of the 20-item Toronto Alexithymia Scale with a sample of Iranian students. Psychol Rep, 101 (1), 209-20.

Bott S, Guedes, A, Ruiz-Celis AP, Mendoza JA (2019). Intimate partner violence in the Americas: a systematic review and reanalysis of national prevalence estimates. Rev Panam Salud Publica, (43).

Brown KW, \& Ryan RM. (2003). "The benefits of being present: Mindfulness and its role in psychological wellbeing". J Pers Soc Psychol, 84, 822-848.

Calvete E, Morea A, Orue L. (2019). The Role of Dispositional Mindfulness in the Longitudinal Associations Between Stressors, Maladaptive

$$
\text { منع و سر كوبخرى استفاده مى كنند (كرير' و همكاران، }
$$

\section{نتيجه كيرى}

بنابراين مطالعه حاضر نشان داد كه بين ناكويى هيجانى و ذهن آكاهى با افسردگى و اضطراب زنان دجار خشونت همسر رابطه وجود دارد و اين دو متغير نقشى معنىدار در بيش بينى افسردگى و اضطراب اين زنان دارند. با توجه به يافتهاى مطالعه حاضر، مىتوان مهارتهاى كاهش ناكويى ناهيجانى و افزايش ذهن آكاهى را در كنار حمايتهاى قانونى به عنوان توانمندسازى فردى كه در اين زنان بحث بسيار مهمى است به ايشان ارائه داد تا

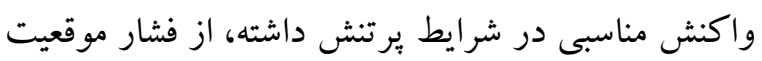
بكاهند و سلامت عمومى و ساز كارى خود را در شرايطى كه ترك زندكى و طلاق مقدور و به صلاح نيست، افزايش دهند. از محدوديتهاى يُزوهش حاضر مىتوان به استفاده از ابزار خود گزارشى (تأثير گذار در سو گيرى

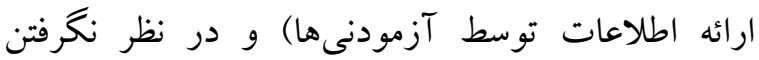
متغيرهايى همجون وضعيت اقتصادى-اجتماعى، ميزان برخوردارى از حمايت اجتماعى و خانوادگى (تأثير گذار در ميزان افسردگى و اضطراب زنان دجار خشونت) بود كه اميد هست در يُزوهشهاى بعدى مورد توجه يثزوهشخران قرار كيرد.

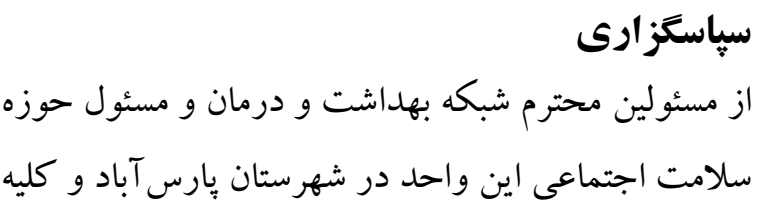

1 - Greer 
Schemas, and Depressive Symptoms in Adolescents. Mindfulness, 10(3), 547-558.

Clements MC, Bennett VE, Hungerford A, Clauss K, Wait SK. (2019). Psychopathology and Coping in Survivors of Intimate Partner Violence: Associations with Race and Abuse Severity. Joumal of Aggression, Maltreatment \& Traum, 27(8), 20-221.

Costa ECV, Gomes SC. (2018). Social Support and Self-Esteem Moderate the Relation Between Intimate Partner Violence and Depression and Anxiety Symptoms Among Portuguese Women. Journal of Family Violence, 33(5), 355-368.

Craparo G, Gori A, Petruccelli I, Cannella V, Simonelli C. (2014). Intimate Partner Violence: Relationships Between Alexithymia, Depression, Attachment Styles, and Coping Strategies of Battered Women. The Joumal of Sexual Medicine, 11(6), 1484-1494.

Duval P, Pietri M, Bouteyre E. (2019). Effect of perceived parent child relations on adjustment of young women exposed to mutual intimate partner violence during childhood. Aggression and Violent Behavior, 47,274-281.

Fang S, Chung MC. (2019). The impact of past trauma on psychological distress among Chinese students: The roles of cognitive distortion and alexithymia. Psychiatry Res, 271,136-143.

Fietz J, Valencia N, Silani G. (2018). Alexithymia and autistic traits as possible predictors for traits related to depression, anxiety, and stress: A multivariate statistical approach. J Eval Clin Pract, 24 (4), 901-908.

Ghahari SH, Khademolreza N, Sadeghi Poya F, Ghasemnejad S, Gheitarani B, Pirmoradi MR. (2017). Effectiveness of Mindfulness Techniques in Decreasing Anxiety and Depression in Women Victims of Spouse Abuse. Asian J Pharmaceut Res Health Care, 9(1), 28-33.

Ghodrati F, Yazdanpanahi Z, Akbarzadeh M. (2019). The Relationship between Religious Attitude and Domestic Violence against Women of Reproductive Age. J Midwifery Reprod Health, 7(1),1522-1526.
Greer JA, Solis JM, Temel JS, Lennes IT, Prigerson HG, Maciejewski PK, Pirl WF. (2011). Anxiety disorders in long-term survivors of adult cancers. Psychosomatics,52, (2): 417423.

Hamaideh SH. (2017). Alexithymia among Jordanian university students: Its prevalence and correlates with depression, anxiety, stress, and demographics. Psychiatr Care, 54(2), 274-280.

Hawcroft C, Hughes R, Shaheen A, Usta J, Elkadi H, Dalton T, Ginwalla Kh, Feder G. (2019). Prevalence and health outcomes of domestic violence amongst clinical populations in Arab countries: a systematic review and metaanalysis. BMCPublic Health, 19(1).

Hemming L, Haddock G, Shaw J, Pratt D. (2019). Alexithymia and Its Associations With Depression, Suicidality, and Aggression: An Overview of the Literature. Front Psychiatry, 10: 203.

Hyphantis T, Paika V, Almyroudi A, Kampletsas ED, Pavlidis N. (2011). Personality variables as predictors of early non-metastatic colorectal cancer patients' psychological distress and health-related quality of life: a one-year prospective study. J Psychosom Res, 70 (5), 411-21.

Ivanoski B, \& Malhi G. (2007). The psychological and neurophysiological concomitants of mindfulness forms of meditation. Acta Neuropsychiatrica, 19(2), 76-91.

Jonker IE, Lako DAM, Beijersbergen MD, Sijbrandij M, Hemert AMV, and Wolf JRLM. (2019). Factors Related To Depression and PostTraumatic Stress Disorder in Shelter-Based Abused Women. Violence Against Women, 25(4), 401-420.

Katz J, Martin AL, Page MG, Calleri V. (2009). Alexithymia and fear of pain independently predict heat pain intensity ratings among undergraduate university students. Pain Res Manag, 14(4),299-305.

Kaviani H, Seyfourian H, Sharifi V, Ebrahimkhani N. (2009). Reliability and validity of Anxiety and Depression Hospital Scales (HADS): Iranian 
patients with anxiety and depression disorders. Tehran Univ Med Sci, 67(5). [Farsi].

Krejcie RV, Morgan DW. (1970). Determining sample size for research activities. Educational and Psychological Measurement,30(1), 607-610.

Lee CSC, Ma MT, Ho HY, Tsang KK, Zheng YY, Wu ZY. (2017). The Effectiveness of Mindfulness-Based Intervention in Attention on Individuals with ADHD: A Systematic Review. Hong Kong J Occup Ther, 2017, 30(1):33-41.

Mayer B, Polak MG, Remmerswaal D. (2019). Mindfulness, Interpretation Bias, and Levels of Anxiety and Depression: Two Mediation Studies. Mindfulness, 10(1), 55-65.

Mozafari Zadeh M, Heidari F, \& Khabiri M. (2019). Effectiveness of mindfulness and acceptance training on reducing sport injury anxiety and improving performance of soccer players. J Rehab Med, 2019; 8(1): 95-108.

Okafor CN, Barnett W, Zar HJ, Nhapi R, Koen N, Shoptaw S, Stein DJ. (2018). Associations of Emotional, Physical, or Sexual Intimate Partner Violence and Depression Symptoms
Among South African Women in a Prospective Cohort Study. J Interpers Violence

Perepelkin J, Antunes K, Luke Boechler L, Remillard

AJ. (2019). Providing mindfulness meditation for patients with depression and anxiety in a community pharmacy: A pilot study. J Am Pharm Assoc, 59(2),258-264.

Schneider MN, Zavos HMC, McAdams TA, Kovas Y, Sadeghi S, Gregory AM. (2019). Mindfulness and associations with symptoms of insomnia, anxiety and depression in early adulthood: A twin and sibling study, 118, 1829.

Slanbekova GK, Chung MC, Karipbaev BI, Sabirova RS. (2019). Postraumatic Stress and Interpersonal Sensitivity: Alexithymia as Mediator and Emotional Expressivity as Moderator. J Loss Trauma, 90(1), 249-261.

Webb CA, Beard C, Forgeard M, Björgvinsson T. (2019). Facets of Mindfulness Predict Depressive and Anxiety Symptom Improvement Above CBT Skills. Mindfulness, 10(3), 559-570. 